marathon season opens, with its expected further huge increase in participants, the public may be said-literally-to be voting with its feet.

J N MORRIS

Emeritus Professor of Community Health,

London School of Hygiene and Tropical Medicine,

London WC1 $7 \mathrm{HT}$

${ }^{1}$ Anonymous. Physical activity and health: a documentation. Scand $\mathcal{f}$ Soc Med 1982;suppl 29:5-269.

${ }^{2}$ Hänninen O, Kukkonen K, Vuori I. Physical training in health promotion and medical care. Ann Clin Res 1982;14, suppl 34:5-172.

${ }^{3}$ Morris JN, Everitt MG, Pollard R, Chave SPW, Semmence AM. Vigorous exercise in leisure-time: protection against coronary heart disease. Lancet 1980;ii:1207-10.

${ }^{4}$ Paffenbarger RS, Wing AL, Hyde RT. Physical activity as an index of heart attack risk in college alumni. Am 7 Epidem 1978;108:161-75.

${ }^{5}$ Pomrehn PR, Wallace RB, Burmeister LF. Ischemic heart disease mortality in Iowa farmers. The influence of life-style. $\mathcal{F} A M A 1982 ; 248$ 1073-6.

${ }^{6}$ Garcia-Palmieri MR, Costas R, Cruz-Vidal M, Sorlie PD, Havlik RJ Increased physical activity: a protective factor against heart attacks in Puerto Rico. Am $\mathcal{F}$ Cardiol 1982;50:749-55.

7 Siscovick DS, Weiss NS, Hallstrom AP, Inui TS, Peterson DR. Physical activity and primary cardiac arrest. $7 A M A 1982 ; 248: 3113-7$.

${ }^{8}$ Rigotti HA, Thomas GS, Leaf A. Exercise and coronary heart disease. Annu Rev Med (in press)

9 Wood PD, Haskell WL. Interrelation of physical activity and nutrition on lipid metabolism. In: White PL, Mondeika T, eds. Diet and exercise: synergism in health maintenance. Chicago: American Medical Association, 1982:39-47.

${ }^{10}$ Ritter JM, Barrow SE, Blair IA, Dollery CT. Release of prostacyclin in vivo and its role in man. Lancet 1983;i:317-9.

${ }^{11}$ Canada Fitness Survey. Canada's fitness. Ottawa: Government of Canada 1982

12 Canada Fitness Survey. Fitness and aging. Ottawa : Government of Canada 1982.

\section{Hypocholesterolaemia and cancer?}

The serum cholesterol concentration of a population can be reduced and this is accompanied by a decrease in the incidence of coronary heart disease. ${ }^{1}$ This observation raises some important questions: can the serum cholesterol concentration be reduced to an excessively low level by diet alone; is a low serum cholesterol concentration harmful; and is there an ideal range for the concentration of serum cholesterol ?

Lewis and coworkers reported a decrease of $29 \%$ in mean serum cholesterol concentration in 12 Trappist monks after taking a modified fat diet supplemented with fibre for five weeks ${ }^{2}$ - a result obtained with optimal compliance over a short period. The Oslo Study Group admitted 1232 healthy normotensive men with serum cholesterol concentrations between 7.5 and $9.8 \mathrm{mmol} / 1$ to a randomised controlled trial to determine the effects of reducing smoking and reducing serum cholesterol concentrations by modifying the diet. ${ }^{1}$ Mean serum cholesterol concentrations were about $12 \%$ lower after five years in the treatment group, who experienced significantly fewer coronary events. This suggests that with appropriate dietary advice the mean serum cholesterol concentration in a population may be reduced by $10-15 \%$ a reduction which can hardly be regarded as excessive.

A highly significant positive correlation was obtained when death rates from different countries for coronary heart disease were compared with those from cancer of the colon. ${ }^{3}$ Rose and coworkers investigated the possibility that a raised serum cholesterol concentration might be a factor common to both diseases. Surprisingly, cancer of the colon was shown to be associated with low concentrations of serum cholesterol. The
Framingham group studied 5209 people prospectively over 24 years, ${ }^{4}$ finding that in men there was a significant inverse association between serum cholesterol concentrations and cancer at several sites, of which cancer of the colon achieved the greatest significance. There are several explanations for this association. Firstly, it may be the effect of competing lethal risks: people with high serum cholesterol concentrations may have died prematurely from ischaemic heart disease while those with low concentrations survived to develop cancer of the colon. Secondly, possibly a low serum cholesterol concentration is a consequence of cancer of the colon rather than a predisposing factor, though if this were true the Framingham patients would have had low cholesterol concentrations for at least 10 years before their cancers were detected. The absorption of cholesterol from the diet is variable but low, decreasing as cholesterol intake increases. The remainder is excreted in the faeces as neutral sterol. ${ }^{5} \mathrm{~A}$ diet with a high content of animal fat will therefore increase the amount of cholesterol entering the colon. A third suggestion, therefore, is that cholesterol acts as a cocarcinogen within the colon. ${ }^{6}$ Finally, a high fat diet stimulates the secretion of bile and bile salts may be converted by bacteria to cocarcinogens within the colon. ${ }^{78}$ This effect may be enhanced if transit time through the colon is slow and the exposure of the colonic mucosa to carcinogens is prolonged. Thus individuals who absorb cholesterol poorly, and ingest a high cholesterol-low fibre diet, might be especially at risk of developing cancer of the colon. ${ }^{9-11}$ In support of this hypothesis, recent work has shown a highly significant positive correlation between cholesterol intake and cancer of the colon. ${ }^{12}$

Possibly a low serum cholesterol concentration may be associated with other aetiological factors contributing to cancer. A diet low in cholesterol may contain synthetic trans fatty acids which could increase the permeability of the colonic mucosa to carcinogenic substances. ${ }^{13}$ Another possibility is that low serum cholesterol concentrations may be associated with low concentrations of plasma retinol. The concentration of plasma retinol and the dietary intake of $\beta$-carotene are inversely related to mortality from cancer. ${ }^{14} 15$ Marenah and coworkers ( $p$ 1603) show a direct relation between low density lipoprotein concentrations and plasma concentrations of retinol and $\beta$-carotene. If hypocholesterolaemia is carcinogenic, what is the mechanism? Oliver suggests that it might be via a reduction in the amount of cholesterol within the membrane of the cell, which alters its fluidity. ${ }^{16}$ Marenah et al examined the cholesterol content and fluidity of monocytes and fibroblasts over a wide range of cholesterol concentrations and conclude "that changes in cell membranes are unlikely to occur at serum cholesterol concentrations attainable by the dietary or drug treatment of hyperlipidaemia."

So what practical conclusions may we draw ? The relationship between low serum cholesterol concentration and cancer is present only in men, whereas that between increased serum cholesterol and heart disease is present in both sexes. Mortality from ischaemic heart disease exceeds that of cancer of the colon at all concentrations of serum cholesterol in men. ${ }^{16}$ Mortality from cancer of the colon is virtually on a plateau between serum cholesterol concentrations of 7.8 and 4.9 $\mathrm{mmol} / \mathrm{l}$, but below this rises quite steeply. Mortality from ischaemic heart disease is on a gently rising curve below a serum cholesterol concentration of about $7.0 \mathrm{mmol} / \mathrm{l}$, but then increases markedly. ${ }^{16}$ Within a population widespread mild hypercholesterolaemia will make a greater contribution to coronary artery disease mortality than a few individuals with severe hypercholesterolaemia. Thus, in the light of 
present knowledge, we could take $6.5 \mathrm{mmol} / 1$ as the upper limit for primary prevention of ischaemic heart disease and $4.9 \mathrm{mmol} / \mathrm{l}$ as the lower limit to avoid the possibility of developing cancer of the colon. Reduction in serum cholesterol concentration should be achieved initially by modification of the fat content of the diet complemented by an adequate intake of $\beta$-carotene and fibre supplied by liberal additions of vegetables, cereals, and fruit.

\section{KENNETH G TAYLOR}

Consultant Physician,

Department of Diabetes, Endocrinology,

and Lipid Metabolism,

Dudley Road Hospital

Birmingham B18 7QH

${ }^{1}$ Hjermann I, Byre KV, Holme I, Leren P. Effect of diet and smoking intervention on the incidence of coronary heart disease. Report from the Oslo study group of a randomised trial in healthy men. Lancet 1981 ;ii:1303-10.

2 Lewis B, Hammett F, Katan M, et al. Towards an improved lipid-lowering diet : additive effects of changes in nutrient intake. Lancet 1981 ;ii:1310-3.

${ }^{3}$ Rose G, Blackburn H, Keys A, et al. Colon cancer and blood-cholesterol. Lancet $1974 ; \mathrm{i}: 181-3$.

4 Williams RR, Sorlie PD, Feinleib M, McNamara PM, Kannel WB, Dawber TR. Cancer incidence by levels of cholesterol. $\mathcal{F} A M A 1981$; $245: 247-52$

${ }^{5}$ Lewis B. Metabolism of plasma cholesterol. In: The hyperlipidaemias. Clinical and laboratory practice. London: Blackwell, 1976:93-119.

${ }^{6}$ Cruse P, Lewin M, Clark CG. Dietary cholesterol is co-carcinogenic for human colon cancer. Lancet $1979 ; \mathrm{i}: 752-5$.

Hill MJ. Metabolic epidemiology of dietary factors in large bowel cancer. Cancer Res 1975;35:3398-402.

${ }^{8}$ Hill MJ. Steroid nuclear dehydrogenation and colon cancer. $\mathrm{Am} \mathcal{F} \mathrm{Clin}$ Nutr 1974;27:1475-80.

${ }^{9}$ Burkitt DP. Epidemiology of cancer of the colon and rectum. Cancer $1971 ; 28: 3-13$.

${ }^{10}$ Burkitt DP, Walker ARP, Painter NS. Dietary fiber and disease. $\mathcal{F} A M A$ $1974 ; 229: 1068-74$.

11 Graham S, Mettlin C. Diet and colon cancer. Am F Epidemiol 1979;109 $1-20$.

${ }^{12}$ Liu K, Stamler J, Moss D, Garside D, Persky V, Soltero I. Dietary cholesterol, fat, and fibre, and colon-cancer mortality. An analysis of international data. Lancet 1979 ;ii :782-5.

${ }^{13}$ Enig MG, Munn RJ, Keeney $M$. Dietary fat and cancer trends-a critique. Fed Proc 1978;37:2215-20.

${ }^{14}$ Wald N, Idle $M$, Boreham J, Bailey A. Low serum-vitamin A and subsequent risk of cancer. Preliminary results of a prospective study. Lancet 1980;ii:813-5.

${ }^{15}$ Shekelle RB, Lepper M, Liu S, et al. Dietary vitamin A and risk of cancer in the Western Electric Study. Lancet 1981 ;ii:1185-9, 90.

${ }^{16}$ Oliver MF. Serum cholesterol-the knave of hearts and the joker. Lancet $1981 ; \mathrm{ii}: 1090-5$.

\section{Antivivisection}

The Cruelty to Animals Act ${ }^{1}$ was passed in its present form in 1876 mainly as a result of pressure from the medical profession led by Dr James Paget. Doctors were well aware of the importance of animal work in advancing medical knowledge but were equally determined to keep out of Britain the horrible practices occurring in some other European countries in the middle of the last century. ${ }^{2}{ }^{3}$ They wanted legislation which would eliminate cruelty, keep the infliction of pain to a minimum by the use of anaesthetics, and ensure licensing and surveillance of animal experiments.

The Act was passed against the wishes of many antivivisectionists for whom nothing less than a total ban of all animal experiments was satisfactory. Their leader at that time was a formidable woman, Frances Power Cobbe, described by a contemporary as being "entirely impervious both to ridicule and reason" and having "inextinguishable eloquence especially in the direction of vituperation," qualities of great value in the leadership of any campaign. ${ }^{4}$
Miss Cobbe's present day successors share with her the ability to stir the emotions of the British public, as is evident from the nationwide campaign by the contemporary antivivisectionists. This is trying to create such a degree of sympathy against animal work among the public that Members of Parliament will be encouraged to introduce highly restrictive measures when debating the Government's proposals for new legislation set out in its white paper Scientific Procedures on Living Animals (Cmnd 8883).

The propaganda is documented by photographs of miserable cats and dogs, by statements that such animals are subjected to cruel, unnecessary, and agonising experiments without anaesthetics, and by misleading accounts of experimental work. Unfortunately responsible organisations such as the Royal Society for the Prevention of Cruelty to Animals are able to quote a few reports from scientific and medical journals of research that seems to have caused unacceptable suffering to animals-examples which give spurious respectability to the whole range of allegations. For example, claims are made that medical schools purchase stolen animals. Such allegations are not only lies but lies that cause great misery to children, families, or old people who may have lost a much loved pet and imagine it cowering in a cage awaiting some atrocious torture.

Each year in Britain 360 million animals are killed for food. The total number of animals used for experimental work in the whole of Britain in a year (1980 Home Office figures $\left.{ }^{5}\right)$ is 4.6 million, and most of the animals are mice $(2.7$ million) and rats $(1.0$ million). Dogs and cats, the animals most frequently referred to in antivivisectionist propaganda, represent $0.4 \%$ of the total.

Most animal experiments ( 3.7 million, or $80 \%$ ) are done without anaesthesia because feeding experiments, taking venous blood, or giving injections, do not require anaesthetics in animals any more than in man. In more extensive procedures anaesthetics are used and are as effective in animals as in man.

The 40 universities in Britain with medical, dental, veterinary, and pharmacy schools or biology departments are responsible for less than one fifth of animal experiments. Commercial concerns and governmental institutions are responsible for most of the others-which are often required by legislation passed by Parliament to protect the public. These requirements may well need to be re-examined-but it is the legislation requiring the tests to be done that needs modification, not the 1876 Act by which the animal work is controlled. Tests on cosmetics have been greatly criticised, but they account for less than $0.7 \%$ of all animal work, and because cosmetics are so bland they seldom cause anything more than transient discomfort when applied to the skin or even the conjunctivae. The justification for these tests is that such materials may be applied with great frequency over months or years to the skin of infants or the faces of adolescents.

A frequent assertion of some antivivisectionists is that animal work could be entirely replaced by work on tissue culture. They ignore the difficulty that the function of an organ or the response of an organism to infection, a malignant growth, or drugs cannot be investigated by studying isolated cells. No culture of mammalian kidney cells can produce urine. A culture of nerve cells tells us little about the complex functions of the brain.

Medical research owes a great deal to animal experiments and so do our patients, both human and veterinary. Every diabetic receiving insulin, everyone who has had a renal transplant, every leukaemic child treated with modern cytotoxic drugs, and, indeed, all who benefit from modern medicines owe a debt to animals. Doctors need not be apologetic 